\title{
日本における食事経由のダイオキシン関連物質の摂取量
}

(平成 3 年 4 月 24 日受理)

$\begin{array}{lll}\text { 高山幸司* } & \text { 宮田秀明* 青笹 } & \text { 治* } \\ \text { 味村真弓* } & \text { 樫本 隆* } & \end{array}$

\section{Dietary Intake of Dioxin-Related Compounds through Food in Japan}

\author{
Koji Takayama, Hideaki Miyata, Osamu Aozasa, Mayumi Mimura \\ and Takashi Kashimoto
}

(Faculty of Pharmaceutical Sciences, Setsunan University: 45-1, Nagaotoge-cho, Hirakata, Osaka, Japan)

\begin{abstract}
On the basis of the total diet-market basket method, about one hundred kinds of food were respectively purchased in 1977, 1985 and 1990 in Osaka, Japan, and they were cooked, divided into 13 groups and frozen at $-40^{\circ} \mathrm{C}$. Dietary intakes of polychlorinated dibenzo-p-dioxins (PCDDs), polychlorinaed dibenzofurans (PCDFs) and coplanar PCBs (Co-PCBs) through food in Japan were studied by using these 39 samples. The total dietary intake of PCDDs and PCDFs was $175 \mathrm{pg}$ TEQ (2,3,7,8-Tetrachlorinated dibenzo-p-dioxin Toxic Equivalent), i. e., 40 pg TEQ/ day of PCDDs and $135 \mathrm{pg}$ TEQ/day of PCDFs. Co-PCBs, having the same toxic effect as PCDDs and PCDFs, gave an estimated intake of $660 \mathrm{pg} T E Q / \mathrm{day}$, which was calculated by using the $2,3,7,8-\mathrm{T}_{4} \mathrm{CDD}$ toxicity equivalency factors reported by Hanberg et al. In addition, it was found that Japanese took about $60 \%$ of the TEQ of the three chemicals in food through fish \& shellifish, daily intakes of which are larger in Japan than in Europe or the USA. It is noteworthy that the dietary intake of Co-PCBs as TEQ was much greater than that of PCDDs or PCDFs.
\end{abstract}

(Received April 24, 1991)

Key words: ポリ塩化ジベンゾ-p-ダイオキシン polychlorinated dibenzo-p-dioxins (PCDDs); ポ リ塩化ジベンゾフラン polychlorinated dibenzofurans (PCDFs); コプラナー PCB coplanar PCBs；食事 food；摂取量 dietary intake； $2,3,7,8$-四塩化ジベンゾ-p-ジオキシン当価量 $2,3,7,8$ tetrachlorinated dibenzo-p-dioxin toxic equivalent (TEQ)

\section{緒言}

ダイオキシン (polychlorinated dibenzo-p-dioxins: PCDDs) 及び polychlorinated dibenzofurans (PCDFs) は極めて毒性1)及び発ガン性2゙が強いことより，環境衛生 上注目されている污染物質である。また，polychlorinated biphenyl (PCBs) のうちオルト位に置換塩 素を持たない coplanar PCBs (Co-PCBs) は, PCDDs, PCDFs 同様に強毒性を示す ${ }^{3)}$ と共に, メチルコラントレ ン型（チトクロムP-448）の薬物代謝酵素を強く誘導す ることから ${ }^{4)}$, 最近, 他の污染物質と異なり, ダイオキシ ン関連物質として総合的に扱い，最強毒性を示す $2,3,7$,

* 摄南大学薬学部：大阪府枚方市長尾峠町 45-1 8-tetrachlorinated dibenzo- $p$-dioxin $\left(2,3,7,8-\mathrm{T}_{4} \mathrm{CDD}\right)$ に換算して毒性評価が行われ始めている5

PCDDs, PCDFs の主な発生源としては, 都市一般廃棄 物及び医療系廃棄物焼却場, 製紙工場及び車の排気ガス などが考えられており, 大気, 水, 土壤, 食品などを通 じて㠌取される量は，アメリカ人で $98 \%{ }^{6}$ ，，カナダ人で $96.3 \%{ }^{7}$ が食物由来と見積もられている.

すでに，著者らも，ダイオキシン関連物質についてム ラサキイガイを指標生物とした海洋污染8)，人体脂肪分 析による人体污染帛及び各種食品污染 ${ }^{10}$ の実態を明らか にしている. また，日本の沿岸魚及び市販魚中の污染実 態を初めて明らかにし, PCDDs, PCDFs のみならず CoPCBs も含めた污染レベルの把握 の必要性を示した ${ }^{11}$. 
加えて, 大阪府, 高知県で採取したトータルダイエット の保存魚介類試料を用いた分析結果より, 日本人におけ るダイオキシン関連物質の人体への影響は, 魚介類摂取 に起因するところが大きいことも示唆した ${ }^{12)}$.

このダイオキシン関連物質の人体への影響を知るため には, 食品全体からの攝取量把握が必要であるが, 日本 では, 1987 年に小野らにより, 唯一PCDDs と PCDFs の摂取量調查が報告されている ${ }^{13)}$. しかし, 分析精度が 格段に向上すると共に, PCDDs, PCDFs の毒性換算係 数 ${ }^{14)}$ む大幅に修正された上, Co-PCBs の換算係数 ${ }^{15)}$ も新 たに提唱された. そこで, 本研究ではダイオキシン関連 化合物の人体への污染源を究明する一環として，大阪府 で採取した 3 年分のトータルダイエット試料を分析し, 日本における食品経由のダイオキシン関連物質の摂取量 をCo-PCBs も含めて調査し, 併せて毒性評価を行った ので報告する。

\section{実験方法}

\section{1. 試料}

1977 年以来食品污染物摄取量調查計画 ${ }^{16)}$ に基づき, 日本各地でトータルダイエットーマーケットバスケット 方式 ${ }^{17)}$ で採取された試料が保存されている。これまでの 調査において，採取場所による極端な差は認められない ことより，今回は，1977, 1985 及び 1990 年に大阪府下 で採取された各 13 , 計 39 検体を日本の代表試料とし た. すなわち, 厚生省発行の食品群別摂取量表 ${ }^{18) ~ 20)}$ の近 畿 I の欄を基にして, 89 の食品カテゴリーを満たす市 販食品を，1977，1985 及び 1990 年にそれぞれ 100, 114 及び 111 品目購入した. その後, 実際の食事形態に 応じて各食品をそのまま, あるいは調理した後 13 群 (Table 1) に大別, 混合ホモジナイズし, $-40^{\circ}$ で保存し たすのを分析用試料とした。なお，1977 及び 1985 年の 試料は国立衛生試験所, 1990 年の試料は大阪府立公衆 衛生研究所より譲渡されたものである。

\section{2. 試薬及び標準品}

試薬及び標準品は, 既報記載のものと同様であ る21〜23). ただし, $\mathrm{AgNO}_{3}$-シリカ, $\mathrm{H}_{2} \mathrm{SO}_{4}$-シリカ及び $\mathrm{KOH}$-シリカゲルの積層カラム ${ }^{21)}$ に使用したシリカゲル は，メクル社製 Kieselgel 60 (70〜230 mesh) を末洗浄 のまま用いた。

\section{3. 精製及び分析法}

試料 20 (油脂類) $~ 100 \mathrm{~g}$ を既法 ${ }^{9}$. 11) に従って抽出, 精製及び分析を行った。 すなわち, ${ }^{13} \mathrm{C}_{12}-2,3,7,8-\mathrm{PCDDs}$ $\left({ }^{13} \mathrm{C}_{12}\right.$ で標識した $2,3,7,8$-位に置換塩素を有する PCDDs 異性体のうち 4 8 塩化体の各 1 成分, $1 \mathrm{ng}$ ずつ), ${ }^{13} \mathrm{C}_{12}-2,3,7,8$-tetrachlorinated dibenzofuran $\left({ }^{13} \mathrm{C}_{12}-2\right.$, 3,7,8-T $\left.{ }_{4} \mathrm{CDF}, 1 \mathrm{ng}\right)$ 及び ${ }^{13} \mathrm{C}_{12}-3,4,3^{\prime}, 4^{\prime}$-tetrachlorinated biphenyl $\left({ }^{13} \mathrm{C}_{12}-3,4,3^{\prime}, 4^{\prime}-\mathrm{T}_{4} \mathrm{CB}, 5 \mathrm{ng}\right)$ を内標準物質とし て試料に添加した後, $1 N \mathrm{KOH}$-エタノール溶液により 室温で 2 時間アルカリ分解を行った。 次に, $n$-ヘキサン
で 2 回抽出後, 脱水, 濃縮し, $\mathrm{AgNO}_{3}$-シリカ, $\mathrm{H}_{2} \mathrm{SO}_{4}^{-}$ シリカ及び $\mathrm{KOH}-$ シリカゲルの積層カラムクロマトグ ラフィーにより精製した。 さらに，中性アルミナカラム クロマトグラフィーにより PCBs 画分と Co-PCBs, PCDDs 及び PCDFs 画分に 2 分画した，後者を室温で 濃縮後， $n$-デカン $20 \mu 1$ に置換し，高分解能ガスクロマ トグラフー高分解能質量分析計 (HRGC-HRMS) を用い て Selected Ion Monitoring (SIM) 法により, 分解能 7000 10000 (10\% valley), 定量下限 0.02〜0.1 ppt で 分析し， ${ }^{13} \mathrm{C}_{12}$ で標識した内標準物質により補正した。

なお, 4〜6 塩化 PCDDs, PCDFs, $7 \sim 8$ 塩化 PCDDs, PCDFs 及び Co-PCBs 分析は，それぞれ Supelco 社製 SP-2331 (30 m $\times 0.25 \mathrm{~mm}, 0.20 \mu \mathrm{m})$, Hewlett $\cdot$ Packard 社製 Ultrabond \#2 $(25 \mathrm{~m} \times 0.32 \mathrm{~mm}, 0.17 \mu \mathrm{m})$ 及び J \& $\mathrm{W}$ 社製 DB-1 $(25 \mathrm{~m} \times 0.32 \mathrm{~mm}, 0.25 \mu \mathrm{m})$ カラムを用い て, HP5890J GC-JEOL SX-102 MS 装置で行った。

\section{結果及び考察}

\section{1. 添加回収試験}

トータルダイエット試料に添加した, ${ }^{13} \mathrm{C}_{12}$ 標識 $\mathrm{T}_{4} \mathrm{CB}, \mathrm{T}_{4} \mathrm{CDF}, \mathrm{T}_{4} \mathrm{CDD}, \mathrm{P}_{5} \mathrm{CDD}, \mathrm{H}_{6} \mathrm{CDD}, \mathrm{H}_{7} \mathrm{CDD}$ 及び $\mathrm{O}_{8} \mathrm{CDD}$ (以下 $4,5,6,7$ 及び 8 塩化体をそれぞれ $\mathrm{T}_{4}, \mathrm{P}_{5}$, $\mathrm{H}_{6}, \mathrm{H}_{7}, \mathrm{O}_{8}$ と略す） の内標準物質より得られた 3 年間 （39 検体）の回収率の平均之標準偏差はそれぞれ $63 \pm$ $17 \%, 73 \pm 19 \%, 75 \pm 22 \%, 88 \pm 24 \%, 89 \pm 24 \%, 78 \pm$ $17 \%$ 及び $70 \pm 15 \%$ であった。 なお，4８塩化の PCDFs の補正はすべて同塩素数を有する PCDDs の回 収率を用いて行った。

\section{PCDDs, PCDFs 及びCO-PCBs 摂取量}

著者らはすでに，大阪府において 1977, 1979, 1989 年及び高知県において 1977, 1979 年に採取した魚介類 (X 群) 試料を用いて, PCDDs, PCDFs 及び Co-PCBs の

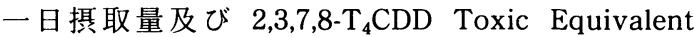
(TEQ) としての摂取量を明らかにしている ${ }^{12)}$. 今回，大 阪府の 1977,1985 年の魚介類を除く 12 試料に加え, 1990 年の全 13 試料を分析した。

食品経由のダイオキシン関連物質の捸取量を調べる場 合, 食品中の濃度が低くても，食品摂取量を乗じた值は 濃度の 9〜200 倍に増加するため (Table 1)，毒性評価を 踏まえて 0.1 ppt 以下の定量下限での分析が望ましい. そこで，今回は，妨害物の影響を大幅に減らすことが可 能な高分解能条件（分解能 $=7000 \sim 10000$ ）で，定量下 限を $0.02 \mathrm{ppt}\left(\mathrm{T}_{4} \mathrm{CDD}\right) \sim 0.1 \mathrm{ppt}$ (Co-PCBs) に設定して 定量を行った。 まず，デー夕解析にあたり，各年度ごと にダイオキシン関連化合物の群別濃度を求めた後, 各群 別食品摂取量を乗じて, 各化合物の食事経由の一日摄取 量を算出し， 3 年間の平均と標準偏差で示した (Table 1 $\sim 3$ ).

大阪府下に在住する人は，平均して一日 $1368 \mathrm{~g}$ の食 品を摂取している (Table 1)。この全食品を通じて, 大阪 


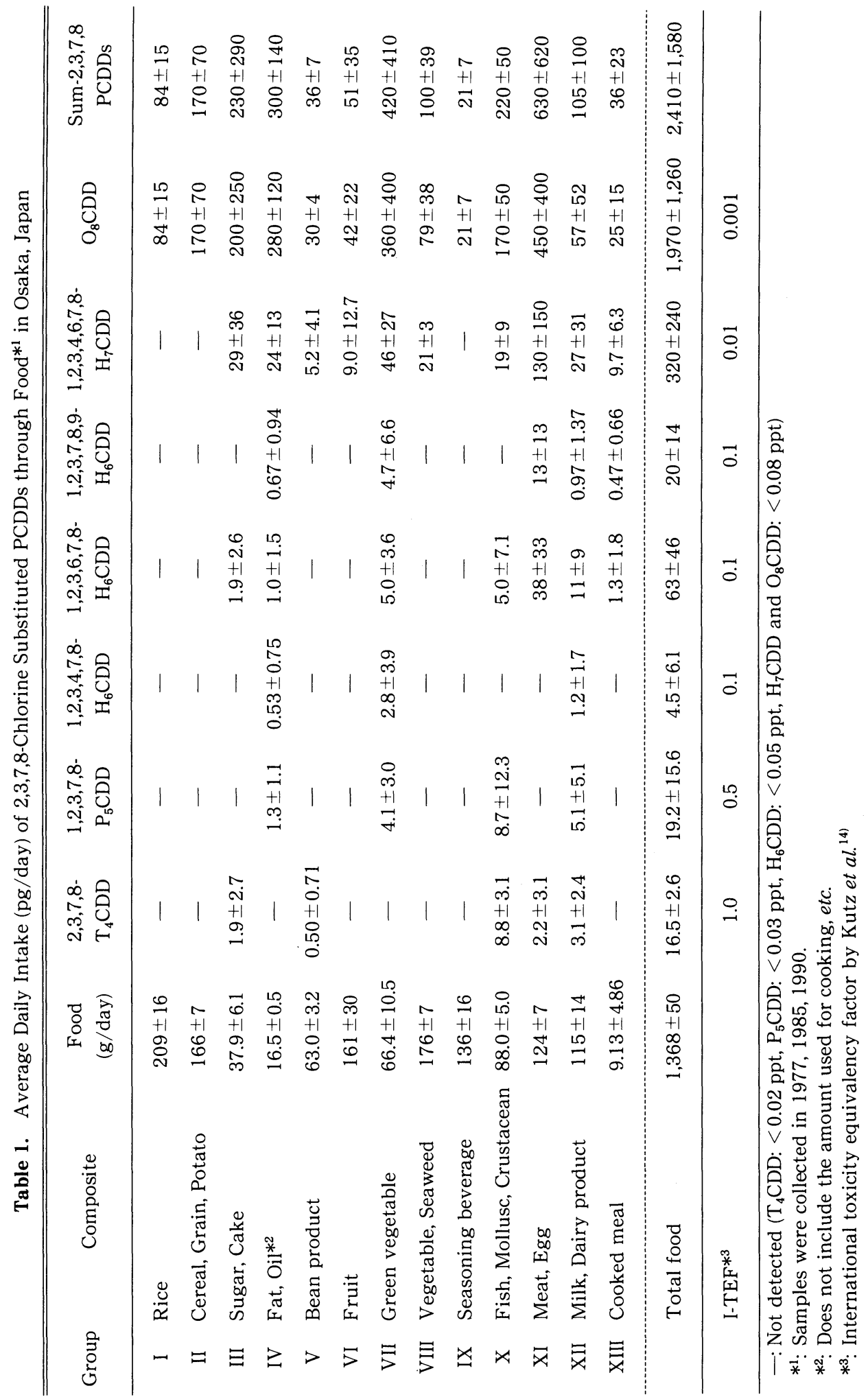




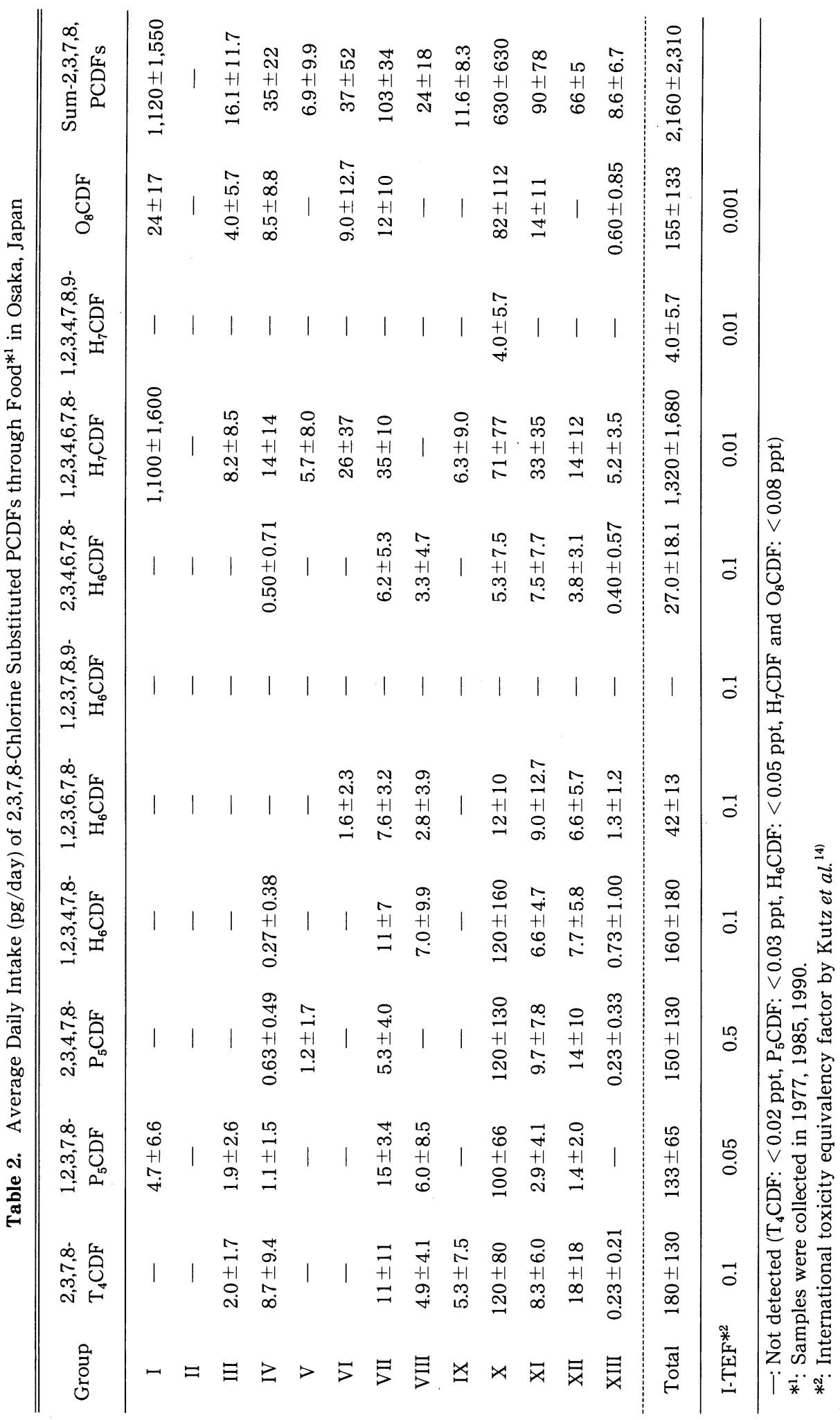


Table 3. Average Daily Intake (pg/day) of Co-PCBs through Food*1 in Osaka, Japan

\begin{tabular}{|c|c|c|c|c|}
\hline Group & $3,4,3^{\prime}, 4^{\prime}-\mathrm{T}_{4} \mathrm{CB}$ & $3,4,5,3^{\prime}, 4^{\prime}-\mathrm{P}_{5} \mathrm{CB}$ & $3,4,5,3^{\prime}, 4^{\prime}, 5^{\prime}-\mathrm{H}_{6} \mathrm{CB}$ & Total \\
\hline I & $1,500 \pm 1,400$ & $17 \pm 25$ & - & $1,500 \pm 1,400$ \\
\hline II & $510 \pm 260$ & $290 \pm 210$ & $200 \pm 290$ & $1,000 \pm 630$ \\
\hline III & $1,000 \pm 1,200$ & $10 \pm 7$ & - & $1,000 \pm 1,200$ \\
\hline IV & $120 \pm 100$ & $26 \pm 30$ & $2.1 \pm 1.9$ & $150 \pm 130$ \\
\hline $\mathrm{V}$ & $4,100 \pm 5,600$ & $33 \pm 36$ & - & $4,100 \pm 5,400$ \\
\hline VI & $260 \pm 130$ & - & - & $260 \pm 130$ \\
\hline VII & $570 \pm 90$ & $57 \pm 14$ & $8.7 \pm 7.4$ & $640 \pm 80$ \\
\hline VIII & $350 \pm 380$ & $6.0 \pm 8.5$ & - & $360 \pm 390$ \\
\hline IX & $880 \pm 1,150$ & $7.0 \pm 9.9$ & - & $890 \pm 1,100$ \\
\hline $\mathrm{X}$ & $35.000 \pm 28,000$ & $2,300 \pm 2,000$ & $270 \pm 380$ & $37,000 \pm 28,000$ \\
\hline $\mathrm{XI}$ & $1,600 \pm 800$ & $900 \pm 540$ & $100 \pm 96$ & $2,600 \pm 1,200$ \\
\hline XII & $220 \pm 200$ & $410 \pm 490$ & $39 \pm 44$ & $670 \pm 730$ \\
\hline XIII & $46 \pm 35$ & $5.8 \pm 7.3$ & $7.7 \pm 10.8$ & $60 \pm 52$ \\
\hline Total & $46,000 \pm 36,000$ & $4,000 \pm 1,500$ & $630 \pm 640$ & $51,000 \pm 34,000$ \\
\hline $\mathrm{TEF}^{* 2}$ & 0.001 & 0.15 & 0.006 & \\
\hline
\end{tabular}

府民は最強毒性の 2,3,7,8-T 4 CDD を一日 $16.5 \mathrm{pg}$ 摂取し ており, その内訳は魚介類 (X 群) $53 \%$, 乳製品（XII 群) $19 \%$ 及び肉類・卵類（XI 群）13\%である.また, 総 2,3,7,8-PCDDs の全食品からの摂取量は $2410 \mathrm{pg} /$ 日 に及んでおり, 高塩素化体ほど摂取量が増える傾向を示 し, 特に $\mathrm{O}_{8} \mathrm{CDD}$ の摂取割合は $82 \%$ にあ及ぶ.この同族 体パターンは, 以前著者らが分析した人体脂肪中の PCDDs 組成とかなり類似したものである ${ }^{9)}$. 内訳を見る 之, 肉・卵類 (XI 群), 緑黄色野菜 (VII 群) 及び油脂類 （IV 群）経由がそれぞれ 630,420 及び $300 \mathrm{pg} /$ 日と多 い. 魚介類 (X 群) は他の群に比べて強毒性の $\mathrm{T}_{4} \mathrm{CDD}$ と $\mathrm{P}_{5} \mathrm{CDD}$ が多いが, $\mathrm{O}_{8} \mathrm{CDD}$ はさほど多くないため, 魚 介類経由の総 2,3,7,8-PCDDs 摂取量は $220 \mathrm{pg} /$ 日にと よ゙まる。

一方，2,3,7,8-PCDFs（2,3,7,8-位に置換塩素を有する PCDFs 異性体）は，全食品より $2160 \mathrm{pg} /$ 日捸取してお り，2,3,7,8-PCDDs と比較した場合，毒性の比較的強い $\mathrm{T}_{4} \mathrm{CDF}$ と $\mathrm{P}_{5} \mathrm{CDF}$ が 1 桁高く, 逆に $\mathrm{O}_{8} \mathrm{CDF}$ が 1 桁低い 傾向が認められる. 食品別に 2,3,7,8-PCDFs 摂取量を比 較すると, 米 (I 群) が $1120 \mathrm{pg} /$ 日で最も多い。これは 1985 年の検体のみより高濃度（3300 pg/日相当）の 1,2,3,4,6,7,8- $\mathrm{H}_{7} \mathrm{CDF}$ が検出されたのに起因するが, まだ 原因不明のため, 検討を要する. 次いで, 魚介類 (X 群), 緑黄色野菜 (VII 群) 及び肉・卵類 (XI 群) 経由がそれ ぞれ 630,103 及び $90 \mathrm{pg} /$ 日と魚介類の影響が大きい.

Table 3 は, ortho 位に塩素原子を持たない non-ortho Co-PCBs についての摂取量を示したものである. 全食 品からの総 Co-PCBs 摂取量は $51 \mathrm{ng} /$ 日に達し, そのう
ち，7割以上が魚介類 (X 群) 経由で, 豆類 (V 群) $8 \%$ 及び肉・卵類 (XI 群) $5 \%$ の寄与率を示す。また, 各異 性体別摂取量を見てむ, いずれの異性体においても魚介 類の寄与が最も多く, 低塩素化体ほどその傾向が強い.

一方, 総食品及びほとんどの食品中の Co-PCBs は, $4 \mathrm{Cl}$ $>5 \mathrm{Cl}>6 \mathrm{Cl}$ の傾向を示すが, 乳製品（XII 群）では毒性 の強い $3,4,5,3^{\prime}, 4^{\prime}-\mathrm{P}_{5} \mathrm{CB}$ が最も多かった.

\section{3. 毒性評価}

PCDDs 及び PCDFs は Kutz ら ${ }^{14)}$ の International toxicity equivalency factor (I-TEF) を, Co-PCBsは Hanberg ら ${ }^{15)}$ の毒性換算係数をそれぞれ該当する食品 別摂取量 (Table 1 3) に乗じて, 各食品経由の平均一日 TEQ 摄取量を見積むった (Table 4). 食事全体で見た場 合, PCDDs 及び PCDFs に起因するものは，それぞれ 40 及び $135 \mathrm{pg} \mathrm{TEQ} /$ 人/日で, 前者よりも後者の TEQ 摂取量の方が大きい。これは，魚介類（X群）で特に PCDFs の影響が 87\% (91 pg TEQ) ああることに起因す るが, 砂糖・ケーキ (III 群) 及び肉・卵類 (XI 群) では むしろ PCDDs の寄与率が大きい. また，米（I 群）の PCDFs 由来が $11 \mathrm{pg}$ TEQ を示すが, 先ほど摂取量の 項で述べたように, 唯一 1985 年の試料において, 摂取 量換算で 1,2,3,4,6,7,8- $\mathrm{H}_{7} \mathrm{CDF}$ が $3300 \mathrm{pg}$ /日検出された ことを考慮すべきである．仮に，この值を除外すると， 米 (I 群) の PCDFs 由来が $0.26 \mathrm{pg}$ TEQ に減少し, 米の 寄与は無視できるレベルとなる。 また, ラット肝ガン細 胞における薬物代謝酵素誘導能を指標にした Hanberg らの係数 ${ }^{15)}$ を用いて Co-PCBs 由来の TEQ 摂取量を算 出すると, PCDDs, PCDFs 由来の 3.8 倍に相当する 660 
Table 4. Average Daily Intake (pg TEQ*1/adult/day) of PCDDs, PCDFs and Co-PCBs through Food*2 in Osaka, Japan

\begin{tabular}{|c|c|c|c|c|c|}
\hline Group & Composite & PCDDs & PCDFs & PCDDs + PCDFs & Co-PCBs \\
\hline I & Rice & $0.1 \pm 0.02$ & $11 \pm 15$ & $11 \pm 15$ & $4.1 \pm 3.4$ \\
\hline II & Cereal, Grain, Potato & $0.2 \pm 0.1$ & - & $0.2 \pm 0.1$ & $46 \pm 33$ \\
\hline III & Sugar, Cake & $2.6 \pm 2.8$ & $0.4 \pm 0.3$ & $3.0 \pm 2.8$ & $2.5 \pm 0.5$ \\
\hline IV & Fat, Oil*3 & $1.4 \pm 0.9$ & $1.5 \pm 1.3$ & $2.9 \pm 2.0$ & $4.0 \pm 4.6$ \\
\hline $\mathrm{V}$ & Bean product & $0.6 \pm 0.7$ & $0.6 \pm 0.9$ & $1.2 \pm 1.7$ & $9.1 \pm 11.0$ \\
\hline VI & Fruit & $0.1 \pm 0.1$ & $0.4 \pm 0.6$ & $0.6 \pm 0.8$ & $0.26 \pm 0.13$ \\
\hline VII & Green vegetable & $4.1 \pm 2.2$ & $7.3 \pm 3.9$ & $11 \pm 6$ & $9.3 \pm 2.1$ \\
\hline VIII & Vegetable, Seaweed & $0.3 \pm 0.1$ & $2.1 \pm 1.8$ & $2.4 \pm 1.8$ & $1.25 \pm 1.65$ \\
\hline IX & Seasoning beverage & $0.02 \pm 0.01$ & $0.6 \pm 0.7$ & $0.6 \pm 0.7$ & $2.0 \pm 1.5$ \\
\hline $\mathrm{X}$ & Fish, Mollusc, Crustacean & $14 \pm 5$ & $91 \pm 91$ & $105 \pm 87$ & $390 \pm 290$ \\
\hline $\mathrm{XI}$ & Meat, Egg & $9.0 \pm 9.3$ & $8.5 \pm 7.1$ & $17.5 \pm 16.2$ & $140 \pm 80$ \\
\hline XII & Milk, Dairy product & $7.4 \pm 6.1$ & $11 \pm 8$ & $18 \pm 13$ & $62 \pm 74$ \\
\hline \multirow[t]{2}{*}{ XIII } & Cooked meal & $0.3 \pm 0.3$ & $0.4 \pm 0.4$ & $0.7 \pm 0.7$ & $0.97 \pm 1.21$ \\
\hline & Total food & $40 \pm 19$ & $135 \pm 120$ & $175 \pm 120$ & $660 \pm 190$ \\
\hline
\end{tabular}

-: Not detected; ${ }^{* 1}$ : TEQs values of PCDDs and PCDFs were calculated using I-TEF by Kutz et al. $^{14)}$ and those of Co-PCBs were did using factor by Hanberg et al. ${ }^{15)}$; ${ }^{2}$ : Samples were collected in 1977, 1985, 1990; *3. Does not include the amount used for cooking, etc.

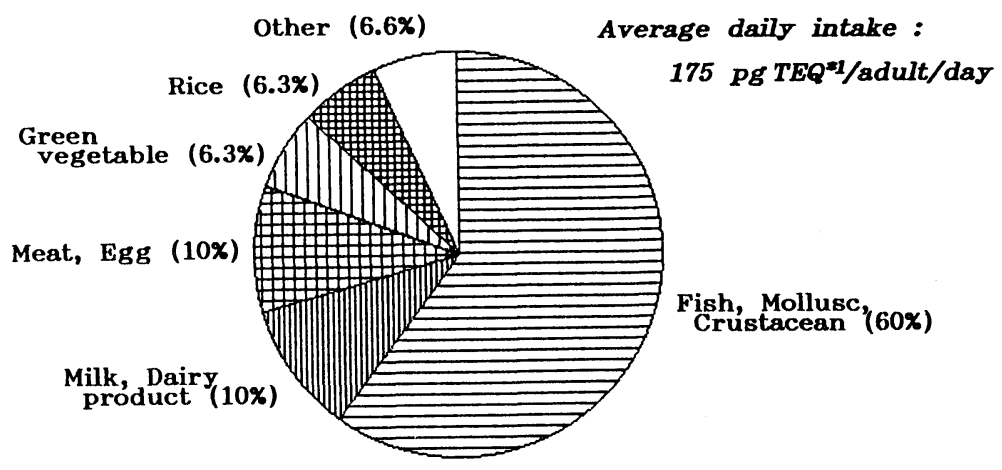

Fig. 1. Contribution (TEQ \%) of PCDDs + PCDFs in food in Osaka, Japan *1: TEQ was calculated using I-TEF by Kutz et al. ${ }^{14)}$

$\mathrm{pg} /$ 成人/日に及んだ.

Fig. 1 及び 2 は, それぞれ, 各食品中の PCDDs, PCDFs 及び Co-PCBs 由来の TEQ を寄与率として図示 したものである.このように，大阪府民が，一日大人一 人当たり食事より摄取している PCDDs, PCDFs 総撕取 量 (175 pg TEQ) のうち，60\% は魚介類（X群）経由 で, 乳製品 (XII 群) 及び肉・卵類 (XI群) が共に $10 \%$ の寄与率を示す (Fig. 1). また, Co-PCBs 由来を見た場 合, PCDDs, PCDFs 同様に, 魚介類 (X 群) 経由が $58 \%$ を占めるが，肉・卵類（XI 群） $21 \%$, 乳製品（XII 群） $9.2 \%$ と, PCDDs, PCDFs 由来よりも肉・卵類の寄与が 大きい (Fig. 2).

1989 年に Beck ら ${ }^{24)}$ は，西ドイッの市販食品などを
分析し，西ドイッ厚生省の換算係数を用いた食品消費に よる PCDDs, PCDFs の一日摂取量を報告している24). 食事経由の PCDDs, PCDFs 総摂取量は $93.5 \mathrm{pg}$ TEQ/ 成人/日で, 主に魚介類 $(35.6 \%)$, 乳製品 (30.4\%) 及び肉 類 (25.1\%) に起因すると報告されている. さらに, Birmingham ら゙ により，カナダ成人についてのデータが 発表され，人体に摂取される総 PCDDs, PCDFs 量は $145.1 \mathrm{pg} \mathrm{TEQ} /$ 日で，そのうち $96.3 \%$ に相当する 139.7 pg TEQ/日は食物由来であること，及び食品別寄与率 は，肉類 $26.2 \%$ ，乳製品 $22.3 \%$ ，卵 $17.5 \%$ で，魚は $12.1 \%$ に相当する $17.0 \mathrm{pg}$ TEQ に過ぎないことが示さ れた.

Beck ら ${ }^{24)}$ の結果は，市販食品を直接分析し，掑取量を 


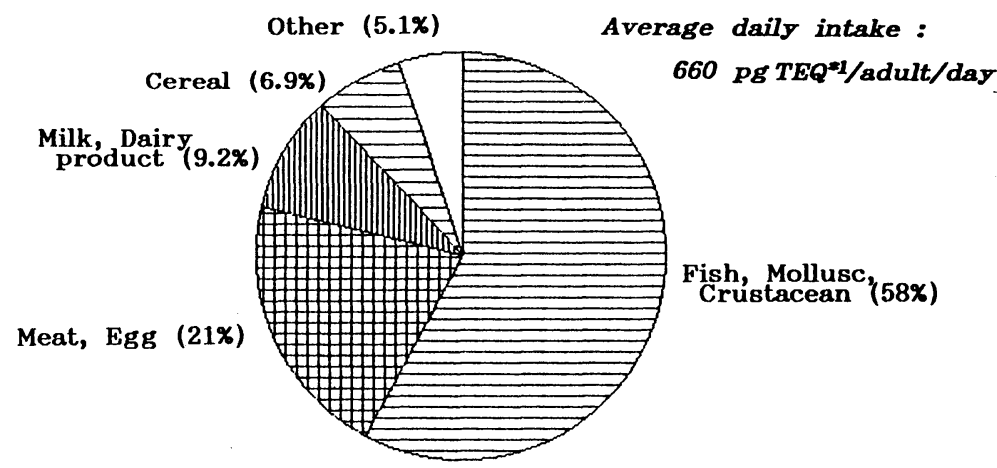

Fig. 2. Contribution (TEQ \%) of Co-PCBs in food in Osaka, Japan *1: TEQ was calculated using factor by Hanberg et al. ${ }^{15}$

乗じて算出されたあのであり, Birmingham らొのデー 夕は，分析済みの各種データを引用して，それに摂取量 を乗じて見積もったあのである，一方，著者らの摂取量 評価は，大阪府民が一日に摄取する 100〜114 食品を実 際の食事形態に応じて，未調理あるいは調理後 13 群に 分類した試料を用いて行ったため, より実状に即した評 価法と考えられる。 今回算出した日本の食事経由の PCDDs, PCDFs 摂取量（175 pg TEQ/成人/日）は, 換 算係数及び試料採取法の違いを考慮しなければならない が，西ドイッ（93.5 pg TEQ/成人/日）及びカナダ （145.1 pg TEQ/成人/日）を上回るものである．我が国 の特徵は, 欧米に比べ魚介類を多食する食生活（カナダ の 44 倍 $^{7)}$ ) 故, 魚介類経由が 6 割を占めることである. また，欧米で注目されている肉類，乳製品む魚介類に次 ぐ主要経路となっているが, 寄与率は相対的に低下して いる.

一方, Co-PCBs は, 污染魚中の濃度及び毒性評価)の 報告はあるが，摄取量については，他に報告例はない， 最近著者らは, 日本の沿岸魚, 市販魚中の PCDDs, PCDFs, Co-PCBs の污染実態11)，及び Co-PCBs が “油 症”においてもPCDFs に次ぐ原因物質であることを明 らかにした ${ }^{25)}$. 今回, Hanberg らの係数を用いて算出し た日本人の食事経由の Co-PCBs 摂取量は, $660 \mathrm{pg}$ $\mathrm{TEQ} /$ 成人/日であるが，最近，Safe はダイオキシン'90 国際学会（ドイッ）において，薬物代謝酵素誘導能以外 に体重增加抑制, 胸腺萎縮などの毒性デー夕を基にし て, 新たに Co-PCBs の毒性換算係数を提案した ${ }^{26)}$ $\left(3,4,3^{\prime}, 4^{\prime}-\mathrm{T}_{4} \mathrm{CB}=0.01,3,4,5,3^{\prime}, 4^{\prime}-\mathrm{P}_{5} \mathrm{CB}=0.1,3,4,5,3^{\prime}, 4^{\prime}\right.$, $\left.5^{\prime}-\mathrm{H}_{6} \mathrm{CB}=0.05\right)$. この值を用いて, Co-PCBs 摂取量を評

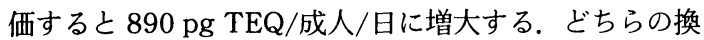
算係数を用いても, Co-PCBs 掑取量は, PCDDs, PCDFs よりもかなり多いことより, Co-PCBs は, PCDDs, PCDFs よりも大きな生物影響を及ぼす可能性が示唆さ れる.
また，日本人の成人体重を $50 \mathrm{~kg}$ として計算した 3.5 $\mathrm{pg} \mathrm{TEQ} / \mathrm{kg}$ 体重/日 (PCDDs, PCDFs) は，諸外国の $\mathrm{ADI}$ 值 $1 \sim 10 \mathrm{pg} / \mathrm{kg}$ 体重/日に接近しており, Co-PCBs 由来の $13.2 \mathrm{pg} \mathrm{TEQ} / \mathrm{kg}$ 体重/日（Hanberg らによる TEF 使用) あるいは $17.8 \mathrm{pg} \mathrm{TEQ} / \mathrm{kg}$ 体重/日（Safe に よる TEF 使用) は, $\mathrm{ADI}$ 值を上回るものである. 以上の ことより，魚介類の寄与がかなり大きい日本では，CoPCBs も含めた食事経由のダイオキシン関連物質の継続 的実態把握が切望される.

謝辞

本研究は, 平成 2 年度文部省科学研究費 (重点領域研 究「人間環境系」）により行った。

本研究に際して, 貴重な試料を提供して頂きました国 立衛生試験所内山 充, 斎藤行生両博士, 並びに大阪府 立公衆衛生研究所西宗高弘博士, 及び両研究所の研究員 各位に深謝致します。

なお，本研究に使用した HRGC-HRMS は昭和 62 年 度文部省科学研究費特別研究の大型共通機器として摂南 大学薬学部に設置された装置を用いた。

\section{文献}

1) McConnell, E. E., Moore, J. A., Haseman, J. K., Harris, M. W.: Toxicol. Appl. Pharmacol. 44, 335 356 (1978).

2) Kociba, R. J., Cabey, O.: Chemosphere 14, 649 660 (1985).

3) Safe, S.: ibid. 14, 791 802 (1987).

4) Yoshimura, H., Yoshihara, S., Ozawa, N., Miki, M.: Ann. N. Y. Acad. Sci. 320, 179 192 (1979).

5) Asplund, L., Grafström, A. -K., Haglund, P., Jansson, B., Järnberg, U., Mace, D., Strandell, M., de Wit, C.: Chemosphere 20, 1,481 1,488 (1990).

6) Travis, C. C., Hattemer-Frey, H. A.: ibid. 16, 2,331 2,342 (1987)

7) Birmingham, B., Gilman, A., Grant, D., Salminen, J., Boddington, M., Thorpe, B., Wile, I., Toft, P., Armstrong, V.: ibid. 19, 637 642 (1989). 
8) Miyata, H., Takayama, K., Ogaki, J., Kashimoto, T., Fukushima, S.: ibid. 16, 1,817 1,822 (1987).

9) Kashimoto, T., Takayama, K., Mimura, M., Miyata, H., Murakami Y., Matsumoto, H.: ibid. 19, 921 926 (1989).

10) Ogaki, J., Takayama, K., Miyata, H., Kashimoto, T.: ibid. 16, 2,047 2,056 (1987).

11）高山幸司, 宮田秀明, 味村真弓, 樫本 隆：衛生化学 37 125 131 (1991).

12) 高山幸司, 宮田秀明, 味村真弓, 樫本 隆：食衛誌. 32 , 108 109 (1991).

13) Ono, M., Kashima, Y., Wakimoto, T., Tatsukawa, R.: Chemosphere 16, 1,823 1,828 (1987).

14) Kutz, F. W., Barnes, D. G., Bottimore, D. P., Greim, H., Bretthauer, E. W.: ibid. 20, $751 \sim 757$ (1990).

15) Hanberg, A., Wærn, F., Asplund, L., Haglund, E., Safe, S.: ibid. 20, 1,161 1,164 (1990).

16）内山 充ら：“昭和 52 年度食品中の各種污染物の実態に 関する調查研究”, 污染物質研究班, 昭和 53 年 3 月.

17) Joint FAO/WHO Food Contamination Monitoring Programme: Guidelines for the Study of Dietary Intakes of Chemical Contaminants (1983), World Health Organization (Geneva).
18）厚生省公䍃衛生局栄養課編：“国民栄養の現状（昭和 49 年度国民栄養調查成積)", (1977) 第一出版, 東京.

19）厚生省保健医療局健康増進栄養課編：“国民栄養の見状 (昭和 57 年度国民栄養調查成績) 京.

20）厚生省保健医療局健康増進栄養課編：“国民栄養の現状 (昭和 62 年度国民栄養調査成績) ${ }^{n}$, (1989) 第一出版, 東 京.

21）樫本 隆, 宮田秀明, 高山幸司, 尾垣淳治: 福岡医誌. 78, 325 336 (1987).

22) Miyata, H., Takayama, K., Ogaki, J., Mimura, M., Kashimoto, T., Yamada, T.: Chemosphere 18, 407 416 (1989).

23）高山幸司, 宮田秀明, 味村真弓, 尾垣淳治, 樫本 隆: 衛 生化学 34, 231 236 (1988).

24) Beck, H., Eckart, K., Mathar, W., Wittkowski, R.: Chemosphere 18, 417 424 (1989).

25) Takayama, K., Miyata, H., Mimura, M., Ohta, S., Kashimoto, T.: ibid. 22, 537 546 (1991).

26) Safe, S., Yao, C., Davis, D.: Development of toxic equivalency factors for polychlorinated biphenyls (PCBs), DIOXIN '90 Organohalogen Compound, 2, 55 59 (1990). 